\title{
A.В. Шурубович
}

\section{БЕАОРУССКАЯ ЭКОНОМИЧЕСКАЯ МОАЕАЬ ПЕРЕА АИЦОМ ТЯЖЕАЫХ ИСПЫТАНИЙ}

Аннотация. В статье рассматриваются основные характеристики белорусской модели социально-экономического развития, реализуемой в последние десятилетия и основанной на доминирующей роли государства в экономике и сильной сочиальной политике. Исследуются причины и проявления нынешнего кризиса этой модели, основные направления ее корректировки.

Ключевые слова: белорусская экономическая модель, государственное регулирование, экономическое развитие, сочиальная сфера, кризис.

Шурубович Алексей Викторович - кандидат

экономических наук, ведущий научный сотрудник

Института экономики Российской академи наук (ИЭ РАН).

E-mail: shurubovich@transecon.ru

\section{A.V. Shurubovich. The Belarusian Economic Model Facing Serious Challenges}

Abstract. The article studies principal characteristics of the Belarusian model of socio-economic development implemented in the last decade and based on the dominant role of the state in economy and strong social policy; the reasons and indicators of the current crisis of this model and the main means of its improvement.

Keywords: Belarusian economic model, the state regulation, economic development, social sphere, crisis.

Shurubovich Alexey Viktorovich - Candidate of Economics,

leading research fellow of the Institute of Economics

of the Russian Academy of Sciences (IE RAS).

E-mail: shurubovich@transecon.ru

Белорусская модель социально-экономического развития, направленная на формирование социально ориентированной рыночной экономики при активной регулирующей роли государства, действовавшая на протяжении более 
20 постсоветских лет и имевшая много положительных результатов, в последние годы стала давать серьезные сбои. Все очевиднее становятся ее издержки, такие как гипертрофированная роль государства в экономике и несоразмерная экономическим возможностям социальная политика. В последние два-три года наблюдается снижение основных экономических показателей и падение материального благосостояния населения. Все это требует серьезной корректировки сложившейся в Республике Беларусь хозяйственной системы: уменьшения масштабов государственного вмешательства в экономику, повышения роли рыночных механизмов и отказа от популизма в социальной политике.

\section{Основные черты и особенности белорусской модели социально-экономического развития}

Белорусская модель социально-экономического развития, реализуемая с середины 1990-х годов, исходит, как отмечает ряд белорусских и зарубежных экспертов, из конкретных белорусских условий и в то же время учитывает опыт экономической трансформации в ряде зарубежных стран ${ }^{1}$. Впервые развернутую характеристику этой модели дал президент А. Лукашенко в марте 2002 г. Он выделил следующие черты белорусской модели развития:

- сильная и эффективная государственная власть, обеспечивающая политическую стабильность, социальную справедливость и безопасность;

- равенство различных форм собственности; главный критерий развития экономики - эффективность ведения хозяйства; приватизация рассматривается не как самоцель, а как средство поиска заинтересованных инвесторов, создание эффективного собственника;

- многовекторность внешнеэкономической политики в условиях глобализации мирохозяйственных связей;

- активизация интеграционных процессов, прежде всего экономических, со странами СНГ и Россией;

- сильная социальная политика государства, инвестиции в здоровье, образование, профессиональное и культурное развитие личности, а также адресная социальная помощь [18, с. 64].

Таким образом, белорусская модель направлена на формирование социально ориентированной рыночной экономики, основанной на ведущей роли государства в хозяйственной жизни и обеспечении высокого уровня социальной защищенности населения. Эта модель, как отмечают ее сторонники,

1. По мнению российского исследователя Ю. Година, «белорусская экономическая модель вобрала во многом в себя черты развития неоиндустриальных развивающихся стран региона Южной, Юго-Восточной и Восточной Азии - от Индии до Южной Kopeu» [8, c. 95]. 
сочетает традиционные принципы функционирования рыночной экономики и специфику национальной экономики Республики Беларусь, традиции и менталитет белорусского народа [3].

В белорусской экономической модели ведущая роль отводится государственному сектору: на долю госпредприятий приходится ныне, по некоторым оценкам, около $50 \%$ ВВП, от госпредприятий поступает около $40 \%$ валютной выручки. На этих предприятиях создано около половины рабочих мест [22, c. 80]. В последние годы доля госпредприятий в экономике несколько снизилась, однако фактически роль госсектора остается решающей. Многие предприятия негосударственной формы собственности представляют собой акционерные общества, в капитале которых значительная доля принадлежит государству. По оценке данной Европейским банком реконструкции и развития (ЕБРР), государство сохраняет доминирующую роль во всех секторах белорусской экономики [1]. Уровень государственных расходов в Республике Беларусь до недавнего времени превышал $40 \%$ ВВП и был значительно выше соответствующего показателя в большинстве стран СНГ и Восточной Европы.

Приватизация проводится медленно и затрагивает в основном малые и средние предприятия, «командные высоты» по-прежнему остаются в руках государства. Переход предприятий в частные руки обставляется многочисленными условиями: крупные инвестиции, сохранение занятости, строительство объектов социально-бытовой сферы и др. Вследствие этого предлагаемые к приватизации активы вызывают мало интереса у инвесторов: так, в 2008-2010 гг. из 34 аукционов по продаже таких активов результативными оказались только семь [19].

Государство оказывает поддержку и частному предпринимательству, рассматриваемому в качестве важного элемента экономической системы страны. В настоящее время негосударственные предприятия, которых к началу трансформации практически не было, создают около половины ВВП; на частный сектор ныне приходится около $60 \%$ всего экспорта страны и половина занятости $[22$, c. 77$]$. Вместе с тем в рамках белорусской модели частному бизнесу изначально отводилась подчиненная роль, что, естественно, сдерживает его развитие.

В экономике Республики Беларусь широко используются административные методы управления. Цены на товары, и прежде всего социальнозначимые товары, регулируются ${ }^{2}$. Для предприятий устанавливаются обяза-

2. По имеющимся оценкам, до последнего времени четверть всех цен в корзине товаров и услуг, по которым определяется индекс потребительских цен, регулировалась государством. В январе 2016 г. белорусское правительство под нажимом международных кредиторов отпустило цены на ряд сочиально значимых продуктов питания (хлеб, молоко, мясо, рыбу, птицу, крупу и детское питание), однако цены на овощи и некоторые другие продукты остаются под государственным контролем. 
тельные для выполнения показатели: в 2014 г. отдельным госпредприятиям было спущено семь такого рода показателей [22, с. 81]. Крупнейшие предприятия, производящие большую часть выпускаемой промышленной и сельскохозяйственной продукции, пользуются внушительной финансовой поддержкой государства (нередко независимо от реальных результатов их деятельности); массовое «закрытие» предприятий с неизбежным резким ростом безработицы не допускается.

Для стимулирования развития важнейших отраслей и крупнейших предприятий применяются разнообразные механизмы: налоговые и таможенные преференции, льготное кредитование (в том числе через недавно созданный Банк развития), частичное субсидирование банковских ставок и др. В 2016 г., по имеющимся оценкам, в Республике Беларусь действовали около 400 налоговых и 300 таможенных льгот. Объем льготных кредитов, предоставляемых в основном крупным госпредприятиям, достигал $43 \%$ от всего объема кредитования [21]. При этом преференции, предоставляемые таким предприятиям, компенсируются достаточно жесткими условиями деятельности массы «обычных» предприятий с преимущественно негосударственной формой собственности. Так, средняя налоговая нагрузка на предприятия составляет $54,8 \%$ к добавленной стоимости, тогда как в России - 47,5, в Казахстане 29,2, в среднем по Европе и Центральной Азии - 33,8\% [7].

По мнению либерального белорусского экономиста К. Рудого, с которым солидарны и некоторые другие эксперты, белорусская экономическая модель, по сути, представляет собой модель государственного капитализма. Характеризуя эту модель, К. Рудый отмечает: «Республика Беларусь - страна, в экономике которой сохраняются высокая доля государственной собственности, командно-административное (“ручное”) управление отдельными предприятиями, консолидация бюджетных ресурсов, высокая занятость в госсекторе и широкая социальная защита. В то же время государственное планирование и управление тесно переплетены с элементами рынка. Директивное кредитование и перекрестный госконтроль сочетаются с деятельностью частных национальных и иностранных предприятий, а также с либерализованным банковским сектором и во многом свободным ценообразованием» $[22$, c. 77$]$.

В отличие от России и ряда других постсоветских стран в Белоруссии значительное внимание уделялось росту платежеспособного спроса населения как фактору подъема экономики. В течение многих лет быстро росли заработная плата и другие виды доходов населения, что дало ряду экспертов основание называть белорусскую экономическую политику «славянским кейнсианством». Обеспечивая повышение жизненного уровня населения, эта политика не только способствовала экономическому росту, но и гарантировала социальную стабильность в стране. 
Активной социальной политике в рамках белорусской модели развития до последнего времени уделялось особое внимание; социальная сфера на протяжении многих лет имела безусловный приоритет. Наряду с неуклонным ростом зарплат, пенсий и пособий широкое распространение получила практика предоставления различного рода льгот. До недавнего времени население оплачивало лишь незначительную часть (в 2012 г. - 12\%) стоимости жилищнокоммунальных услуг, основная тяжесть оплаты которых ложилась на предприятия в рамках «перекрестного субсидирования». Принимались меры по недопущению сильного социального расслоения, проводилась политика перераспределения доходов в пользу малообеспеченных слоев населения. В этой связи некоторые эксперты говорили о наличии своего рода «социального контракта» между властью и обществом, в соответствии с которым общество соглашается на жесткий контроль государства над экономикой и другими сферами общественной жизни в обмен на гарантированные социальные льготы.

Характерной чертой белорусской модели стала высокая степень централизации управления. Все ключевые вопросы экономической политики решаются лично президентом А. Лукашенко, наделенным необходимыми для этого полномочиями.

В рамках белорусской модели реализуется курс на обеспечение многовекторности внешнеэкономических связей. В настоящее время республика имеет торговые отношения более чем с 200 странами мира; при этом основными торговыми партнерами являются страны СНГ, на долю которых в 2015 г. приходилось 56,9\% внешнеторгового оборота Республики Беларусь, а также страны Евросоюза (25,3\%) [2].

Вместе с тем приоритетными экономическими партнерами Белоруссии несомненно являются Россия и другие страны СНГ, активизация интеграционных процессов с которыми, как уже отмечалось, названа президентом Лукашенко в числе основных черт белорусской модели развития. Руководство республики, несмотря на ряд проблем в двусторонних отношениях, проводит курс на сближение и интеграцию с Россией в рамках создаваемого двумя странами Союзного государства. Экономическая интеграция с Россией имеет для Белоруссии жизненно важное значение. Обширный российский рынок открывается для белорусских товаров, благодаря льготным ценам облегчается доступ к российским энергоносителям, обеспечивающим подавляющую часть потребностей Белоруссии в газе и нефти.

Белоруссия активно участвует и в развертывающихся на евразийском пространстве интеграционных процессах на многосторонней основе (прежде всего в рамках начавшего работать с января 2015 г. Евразийского экономического союза (ЕАЭС), в который входят Россия, Белоруссия, Казахстан, Армения и Киргизия). Белорусское руководство стремится использовать евразий120 
скую интеграцию для решения стоящих перед страной актуальных задач (в частности, модернизации экономики республики).

\section{"Белорусское экономическое чудо" и его основные факторы}

Годы реализации белорусской экономической модели (прежде всего период 1996-2008 гг.) были в целом весьма успешными. Белорусская экономика не только достаточно быстро преодолела последствия глубокого трансформационного спада первой половины 1990-х годов, но и добилась значительного роста основных экономических показателей. Белоруссия, в отличие от большинства других постсоветских стран, избежала деиндустриализации, сохранив важнейшие отрасли промышленности и крупнейшие предприятия, и удвоила свой ВВП по сравнению с 1991 г. (табл. 1). Особенно успешными для белорусской экономики были 2000-е годы: согласно данным МВФ, среднегодовой прирост ВВП в 2001-2010 гг. составил 7,4\% и был одним из самых высоких в мире [17, с. 37]. Следует при этом подчеркнуть, что столь значительный экономический рост был достигнут в стране, лишенной крупных запасов энергоресурсов, в условиях почти полного прекращения (во многом по политическим мотивам) предоставления республике западных кредитов ${ }^{3}$. В мире заговорили о «белорусском экономическом чуде».

В последние годы страна приступила к модернизации экономики на инновационной основе. Так, в ходе выполнения Государственной программы инновационного развития на 2011-2015 гг. было введено в эксплуатацию 136 новых предприятий и производств, создано или модернизировано более 19 тыс. рабочих мест [5].

Значительные успехи были достигнуты в развитии социальной сферы Республики Беларусь. С 1996 по 2014 г. непрерывно росли реальные располагаемые доходы населения и реальные зарплаты, что было связано как с быстрым ростом экономики страны, так и с активной социальной политикой государства. Реальная среднемесячная зарплата в 2000 г. составляла лишь 92\% к уровню 1991 г., а в 2014 г. $-445 \%$ [11, с. 130; 26, с. 26].

Серьезным достижением стало резкое снижение числа малообеспеченных жителей: в 2000 г. уровень среднедушевых располагаемых ресурсов был ниже бюджета прожиточного минимума у 41,0\% населения, а в 2014 г. лишь у 4,8\% [26, с. 122]. По данным международных организаций, Белоруссия входит в десятку стран с наименьшим социальным неравенством; разрыв

3. Крупномасштабное кредитование Белоруссии со стороны международных финансовых институтов (прежде всего МВФ) возобновилось лишь в 2009 г. в период мирового кризиса. 
РОССИЯ И МИР В ХХІ ВЕКЕ

в доходах между наиболее богатыми и наиболее бедными в Республике Беларусь примерно такой же, как в Германии, Австрии и Швеции.

Таблица 1

\section{АИНАМИКА ОСНОВНЫХ СОЦИАЛЬНО-ЭКОНОМИЧЕСКИХ ПОКАЗАТЕАЕЙ БЕАОРУССИИ \\ В 1992-2015 гг. (в \% к 1991 г., в сопоставимых ценах)}

\begin{tabular}{|l|c|c|c|c|c|c|c|c|c|}
\hline \multicolumn{1}{|c|}{ Показатели } & 1995 & 2000 & 2005 & 2010 & 2011 & 2012 & 2013 & 2014 & 2015 \\
\hline ВВП & 66,1 & 89,7 & 128,7 & 182,6 & 192,8 & 196,1 & 198,1 & 201,4 & 193,6 \\
\hline $\begin{array}{l}\text { Продукция про- } \\
\text { мышленности }\end{array}$ & 62 & 102 & 152 & 220 & 240 & 254 & 242 & 247 & 231 \\
\hline $\begin{array}{l}\text { Продукция сель- } \\
\text { ского хозяйства }\end{array}$ & 77 & 75 & 94 & 117 & 124 & 133 & 127 & 131 & 127 \\
\hline $\begin{array}{l}\text { Инвестиции } \\
\text { в основной ка- } \\
\text { питал }\end{array}$ & 37 & 50 & 89 & 205 & 242 & 213 & 233 & 220 & 186 \\
\hline $\begin{array}{l}\text { Розничный това- } \\
\text { рооборот (все } \\
\text { каналы реализа- } \\
\text { ции) }\end{array}$ & 49 & 120 & 258 & 499 & 544 & 621 & 733 & 776 & 778 \\
\hline $\begin{array}{l}\text { Реальные распо- } \\
\text { лагаемые денеж- } \\
\text { ные доходы } \\
\text { населения }\end{array}$ & 64 & 101 & 172 & 292 & 289 & 351 & 408 & 412 & 389 \\
\hline
\end{tabular}

Источники: [10, с. $65,113,155,187,229 ; 26$, с. 28$]$.

Социальная ситуация в Белоруссии характеризуется также относительной стабильностью рынка рабочей силы и низким уровнем зарегистрированной безработицы. Этот уровень, увеличившись с $0,05 \%$ в 1991 г. до $3,9 \%$ в 1996 г., в последующие годы имел тенденцию к снижению и достиг $0,5 \%$ в 2014 г. [20, с. $326 ; 23$, с. 147].

При анализе несомненных достижений Республики Беларусь закономерно возникает вопрос: насколько эти достижения обусловлены реализацией избранной белорусским руководством модели социально-экономического развития, и насколько - другими, не связанными с ней факторами. Мнения экспертов разделились.

На наш взгляд, белорусская экономическая модель в первые годы своего существования в целом сыграла позитивную роль в обеспечении восстановления и роста экономики после трансформационного спада. Созданная в республике система хозяйствования, в течение длительного времени обеспечивавшая концентрацию национальных ресурсов на перспективных направлениях, в сложный период 1990-х - начала 2000-х годов способствовала сохранению основы экономического потенциала страны, дала импульс 
модернизации экономики ${ }^{4}$. На первом этапе модернизации только государство реально могло быть ее главным субъектом: ввиду отсутствия крупного частного бизнеса государству приходилось брать на себя его функции.

Сильная социальная политика, направленная на быстрый рост жизненного уровня населения и выравнивание доходов различных его групп, позволила избежать резкого социального расслоения и обеспечить политическую стабильность. Курс на активизацию интеграционных процессов с Россией и другими странами СНГ позволил республике получать весомые выгоды от взаимного сотрудничества. Вместе с тем существенную роль в успешном социально-экономическом развитии Республики Беларусь играли и другие факторы, в том числе сохранявшаяся на протяжении большей части 2000-х годов благоприятная внешнеэкономическая конъюнктура.

Важными факторами бурного экономического роста были, в частности, быстро растущий (во многом благодаря сильной социальной политике государства) внутренний потребительский спрос и инвестиции в основной капитал, осуществляемые в основном государством или прямо (через бюджет) или из средств контролируемых государством предприятий и банков. Как видно из таблицы 1 в 2014 г. розничный товарооборот - главный индикатор внутреннего потребительского спроса - возрос по сравнению с 1995 г. в 15,8 раза, инвестиции - в 5,9 раза.

Существенной особенностью белорусской экономики является ее огромная зависимость от внешних условий, в том числе от состояния экономик стран-партнеров и динамики внешнеторговых цен на основные экспортные и импортные товары. В 2000 - начале 2010 г. эти условия были для Белоруссии достаточно благоприятными. Значительно выросли внешнеторговые цены на многие белорусские экспортные товары, в частности на нефтепродукты, калийные удобрения, черные металлы, тракторы, грузовые автомобили, молоко и молочную продукцию. В соответствии с интеграционными соглашениями Белоруссия, несмотря на наблюдавшийся до недавнего времени рост мировых цен, получает из России энергоресурсы (прежде всего нефть и природный газ) по льготным ценам, благодаря которым она сэкономила за последние 15 лет, по различным оценкам, 70-80 млрд долл. Российский «интеграционный грант» в виде льготных поставок энергоресурсов в 2011 г. составлял $10 \%$, в 2012 г. $-14 \%$ ВВП республики [15, с. 93]. Получая из России нефть по льготным ценам, Республика Беларусь поставляла на Запад произведенные из нее нефтепродукты по растущим мировым ценам, что обеспечивало ей значительные доходы.

4. Даже критически относящчеся к белорусской модели эксперты (в частности, российский политолог Е. Минченко) признают спасение промымленности важным положительным итогом проводимой в РБ экономической политики [12]. 
В последние годы, однако, внутренние и особенно внешние условия значительно ухудшились, что резко осложнило экономическую ситуацию в стране.

\section{Кризис белорусской модели, его причины и проявмения}

Реализуемая в Республике Беларусь экономическая модель имеет, как отмечают многие белорусские и зарубежные эксперты, серьезные внутренние изъяны. Доминирование государственной собственности и «зарегулированность» хозяйственной жизни серьезно затрудняют создание конкурентной среды, необходимой для повышения эффективности экономики. Ресурсов государства и госпредприятий явно недостаточно для успешного проведения модернизации экономики. Низкий уровень экономической свободы, сдерживая приток частных (в том числе иностранных) инвестиций, ограничивает финансовые ресурсы этой модернизации. Массированное льготное кредитование экономики в течение многих лет имело своей обратной стороной резкое увеличение денежной массы и, соответственно, высокий уровень инфляции (в течение многих лет инфляция в Белоруссии была одной из самых высоких в СНГ). Преимущественная поддержка крупных госпредприятий ставит в заведомо невыгодное положение частные предприятия, мешая им реализовать свои возможности на рынке.

Социальная политика, направленная на быстрое повышение благосостояния населения и сохранение высокого уровня занятости, до последнего времени недостаточно учитывала реальную экономическую ситуацию и в значительной мере носила популистский характер. Реальные доходы населения и реальная зарплата росли гораздо быстрее, чем производительность труда ${ }^{5}$; при официальном уровне безработицы около $1 \%$ избыточная занятость на госпредприятиях достигает $10-15 \%$. Более $40 \%$ домашних хозяйств пользуются различными льготами, что создает чрезмерную нагрузку на бюджет. Руководство Республики Беларусь до последнего времени стремилось удержать на достигнутом уровне социальные расходы. Это достигалось ценой сокращения вложений в производство, науку, образование, что в условиях сокращения ресурсной ренты, получаемой от РФ, сделало неизбежным рост государственного долга (внутреннего и внешнего). Внешний госдолг увеличился с 0,35 млрд долл. в конце 2001 г. (2,9\% ВВП) до 13,5 млрд долл. на 1 ноября 2016 г. (28,1\% ВВП), превысив пороговый уровень $25 \%$, а совокуп-

5. В 2014 г. реальные располагаемые доходы населения составили 425,0\% к уровню 2000 г., реальная зарплата - 483,5\%, тогда как производительность труда по ВВП лишь $220,6 \%$ [26, с. 26]. 
ный размер внешнего и внутреннего госдолга составил на 1 ноября 2016 г. около 18 млрд долл. [25].

Как отмечает белорусский экономист М. Аникеев, «в среднесрочном периоде централизованные экономические системы могут демонстрировать впечатляющие темпы роста за счет мобилизации, быстрого накопления капитала, концентрации и перераспределения ресурсов в приоритетные сектора экономики и т.д. Однако в долгосрочном периоде накопление... системных проблем неизбежно приводит к угасанию экономического роста и стагнации (или даже снижению уровня производительности экономики)» [1]. Это положение в значительной мере относится и к экономической системе Республики Беларусь.

Белорусская экономическая модель, на наш взгляд, в основном исчерпала свои возможности уже в начале 2000 -х годов, когда этап восстановительного роста закончился и перед страной встали новые задачи, требующие иных подходов к экономике. Продлить ей жизнь помогли уже упоминавшиеся исключительно благоприятные внешнеэкономические условия на протяжении большей части 2000 -х годов. Благодаря сочетанию ряда благоприятных факторов, обеспечивших быстрый экономический рост в течение нескольких лет, появилась иллюзия исключительной успешности белорусской модели.

В 2010-е годы внешние условия для Белоруссии значительно ухудшились. После мирового финансового кризиса 2008-2009 гг. динамика белорусской внешней торговли, объем которой в предыдущие годы быстро увеличивался, стала неустойчивой, с очевидной тенденцией к снижению, отчетливо проявившейся в 2015-2016 гг. ${ }^{6}$ Этот спад был в значительной мере вызван внешними шоками: трудностями в развитии экономик главных торговых партнеров - России и (в меньшей степени) стран ЕС, нестабильностью мировых цен и валютных курсов и др. В связи с колебаниями цен на энергоносители и ухудшением экономической ситуации в РФ существенно сократился российский «интеграционный грант», составив в 2013 г. 8,3\%, в $2014-7,7$ и в 2015 г. 5\% ВВП Республики Беларусь [15, с. 93]. По некоторым оценкам, в 2016 г. этот грант «сжался» до 1,1\% ВВП [13].

Серьезно ухудшилась в последние годы и общая экономическая ситуация в Белоруссии. Среднегодовые темпы прироста ВВП, достигавшие в 19962000 гг. 6,3\%, в 2001-2005 - 7,5, в 2006-2010 - 7,3, в 2011-2015 гг. снизились до $1,2 \%$; заметно упали также темпы прироста других ключевых экономических показателей. В 2015-2016 гг. впервые за длительный период в белорус-

6. В 2015 2. внешнеторговый оборот Республики Беларусь снизился на 25,6\%, в том числе экспорт - на 26, в 2016 г. - соответственно на 11,8 и 13,3\%. 
ской экономике был зафиксирован серьезный спад ${ }^{7}$. Экономические трудности привели к заметному снижению жизненного уровня населения: реальные располагаемые доходы в 2015 г. упали на 6\% [10, с. 393], а в 2016 г., по предварительным данным, на 7,5\% [24]. Номинальная среднемесячная зарплата в долларовом эквиваленте снизилась с 589,9 долл. в 2014 г. до 413,4 - в 2015 г. и до 354,3 долл. в январе-сентябре 2016 г. [21].

Руководство Республики Беларусь связывает нынешние экономические трудности страны в основном с неблагоприятными внешними условиями (так, президент Лукашенко заявил, что нынешний кризис на $80 \%$ обусловлен действием внешних факторов). Однако, на наш взгляд, этот кризис имеет прежде всего внутренние причины и во многом связан с усиливающейся неэффективностью белорусской экономической модели; внешние трудности лишь обнажили ее слабость.

В резко осложнившихся внешних условиях многие белорусские предприятия (особенно крупные госпредприятия), за долгие годы «избалованные» щедрой государственной поддержкой и не привыкшие к жесткой конкуренции, оказались неспособны успешно действовать на все более требовательном внешнем рынке, заметно уступая конкурентам по соотношению «цена качество». Объем неэнергетического экспорта Республики Беларусь в последние годы «просел» на 26\% [13]; в результате резко снизился приток необходимой стране иностранной валюты.

Ослабли позиции белорусских предприятий и на внутреннем рынке: так, при наличии двух собственных производителей телевизоров доля импортных телевизоров на внутреннем рынке доходит до $85 \%$, при развитой легкой промышленности импортируется почти половина обуви и одежды [19]. В результате растет число убыточных и малорентабельных предприятий. Доля таких предприятий (убыточных или имеющих рентабельность менее 5\%) составляет, по некоторым оценкам, около $50 \%$ общего количества предприятий. Государство вынуждено оказывать поддержку этим предприятиям, потому что они имеют не только экономическое, но и важное социальное значение, обеспечивая занятость значительному числу работников. Необходимость их финансовой поддержки требует перераспределения ресурсов от финансово устойчивых, высокопродуктивных предприятий, что наносит ущерб экономике, снижая ее производительность [1]. Вместе с тем в условиях кризиса возможности этой поддержки резко уменьшаются, что усугубляет экономические трудности в стране.

7. В 2015 2. ВВП Республики Беларусь снизился на 3,9\%, продукиия промышленности - на 6,6, инвестиции в основной капитал-на 15,2\% [10, с. 65, 113, 197]. В 2016 2. соответствующие показатели, по предварительным данным, снизились соответственно на 2,6\%, 0,4 и $17,9 \%$ [24] 
Немалый ущерб нанесла стране и слишком «сильная» социальная политика. Быстрый рост доходов населения в условиях «открытости» экономики и относительно низкого качества продукции многих белорусских предприятий привел к увеличению спроса не на отечественные, а на импортные товары и на иностранную валюту, обозначив серьезный сбой «славянского кейнсианства». Наиболее ярко это проявилось в 2011 г., когда повышение зарплаты до эквивалента 500 долл. в соответствии с предвыборным обещанием Лукашенко, совпало по времени со значительным повышением мировых цен на энергоносители и с ажиотажным спросом на легковые автомобили накануне повышения ввозных пошлин на них. Это привело к всплеску инфляции ${ }^{8}$ и «обвалу» курса белорусского рубля, упавшего по отношению к доллару с 3000 бел. руб. за 1 долл. в конце 2010 г. до 8350 - в конце 2011 г. [10, с. 281-282]. В условиях кризиса государство оказалось не в состоянии выполнять возросшие социальные обязательства.

Кризис белорусской экономической модели признается ныне все большим числом экспертов как в самой Республике Беларусь, так и за ее пределами. «Несмотря на социальные достижения прошлых лет, - отмечает, например, директор отдела Украины, Белоруссии и Молдавии Всемирного банка М. Райнер, - экономическая модель Белоруссии исчерпала свои возможности» [4]. Международные финансовые институты на Западе и на Востоке, прежде всего МВФ и Евразийский фонд стабилизации и развития (ЕФСР), настойчиво ставят вопрос о серьезных изменениях в белорусской экономической системе, обусловливая их проведением предоставление стране крупных кредитов, остро необходимых ей в условиях кризиса. Необходимость таких изменений по существу стала общепризнанной, и их проведение выдвигается в число главных задач экономической политики.

\section{Корректировка белорусской модели и ее основные направления}

В последние годы в республике начались достаточно серьезные, на наш взгляд, хотя и не однозначные по своим последствиям преобразования, во многом выходящие за рамки белорусской модели. Эти преобразования реализуются по нескольким направлениям.

В денежно-кредитной сфере проводится достаточно жесткая политика, направленная на существенное ограничение объемов кредитования в целях борьбы с инфляцией. В начале 2015 г., например, была установлена и более года удерживалась ставка рефинансирования в размере $25 \%$ при годовой

8. Если в 2010 г. индекс потребительских иен (декабрь к декабрю предыдущего года) составил 109,4\%, то в 2011 г. $208,7 \%$ [10, с. 285$].$ 
инфляции за 2014 г. 16,2\%; впоследствии эта ставка неоднократно снижалась, но оставалась значительно выше уровня инфляции. Таким образом закончился период дешевого кредита, бывшего одним из «столпов» белорусской модели. Жесткая денежно-кредитная политика имела ограничения (так, ряд крупных «системообразующих» предприятий получал банковские кредиты под 9\% годовых, тогда как ставка для небольших частных предприятий доходила до 35\%), но в целом она выполнила свою роль. Инфляция в Белоруссии снизилась до $12 \%$ в 2015 г. и 10,6\% в 2016 г., хотя это было достигнуто ценой «обескровливания» реального сектора экономики и падения производства в основных отраслях.

Значительная либерализация наблюдается в области регулирования деятельности субъектов хозяйствования. Сокращается число госпредприятий, которым централизованно устанавливаются прогнозные (а по существу плановые) показатели: если в 2010 г. таких предприятий было 140, то уже в 2013 г. - только 77 [22, с. 81]. Были приняты меры в области налогообложения, позволившие заметно сократить для субъектов хозяйствования бремя налогов и сборов; стало существенно легче зарегистрировать или ликвидировать предприятие, получить разрешение на строительство и т.д.

В Программе социально-экономического развития Республики Беларусь на 2016-2020 гг., принятой в июне 2016 г., провозглашен окончательный отказ от регулирования цен и тарифов (за исключением цен монополистов), одобрен мораторий на ухудшение налогового законодательства; вновь созданным предприятиям в районах обещано двухлетнее освобождение от уплаты налогов на прибыль и недвижимость [6]. Предполагается активизировать процесс приватизации государственной собственности.

В связи с уменьшением финансовых возможностей государства существенные изменения происходят в сфере социальной политики. Так, в соответствии с Указом президента Республики Беларусь от 11 апреля 2016 г. № 137 «О совершенствовании пенсионного обеспечения» пенсионный возраст, составлявший на тот момент 60 лет для мужчин и 55 - для женщин, с 1 января 2017 г. будет в течение шести лет ежегодно повышаться на шесть месяцев.

В соответствии с требованиями международных кредиторов взят курс на постепенный отказ от предоставления населению льгот по оплате жилищнокоммунальных услуг (ЖКУ). Уже в 2017 г. население должно будет оплатить $75 \%$ стоимости ЖКУ, а в 2018 г. - все $100 \%$.

Все эти и некоторые другие меры, принимаемые в последнее время белорусскими властями, дают ряду экспертов почву для утверждений о фактическом отказе руководства страны от модели социально ориентированной рыночной экономики. Так, по мнению директора исследовательского центра BEROC E. Борнуковой, «в стране идет постепенный распад социального контракта... Растет уровень безработицы, убираются субсидии на ЖКУ, идет 
пенсионная реформа... Перезаключение социального контракта в ближайшие годы будет одним из главных вопросов повестки дня» [14]. Еще более определенно высказывается Е. Пожидаев, по мнению которого «по сути “уникальная белорусская модель” существует уже в основном по инерции - активы остаются в госсобственности потому, что их не удается продать, а демонтаж “социального государства" практически предрешен» [19].

На наш взгляд, такие оценки являются преждевременными. Белорусская модель, хотя и подверглась в последние годы корректировке, сохраняет пока свою основу - доминирующую роль государства в экономике. Главным ее гарантом остается президент Лукашенко, неоднократно высказывавшийся в последнее время против отказа от созданной им хозяйственной системы 9 Однако направление движения в сторону серьезных преобразований в этой системе совершенно очевидно.

\section{Перспективы белорусской модели: Возможны варианты}

В белорусском руководстве и в экспертной среде в последнее время идут оживленные дискуссии о дальнейшей судьбе белорусской экономической модели: переходить ли, как предлагают сторонники радикальных реформ, уже в ближайшее время на новую модель, предполагающую форсированное внедрение рыночных отношений, всестороннюю либерализацию хозяйственной жизни, крупномасштабную приватизацию, ослабление роли государства в экономике или вносить существенные коррективы в действующую модель без радикальной ломки.

На наш взгляд, в ближайшей перспективе предпочтительным является второй путь, предполагающий «мягкий демонтаж» белорусской модели. Форсированный переход к рыночным отношениям, как отмечают многие белорусские экономисты, чреват непредсказуемыми экономическими и социальными последствиями. Так, в случае массовой приватизации или банкротства неэффективных предприятий с проблемой безработицы могут столкнуться, по имеющимся оценкам, почти $50 \%$ всех занятых в экономике, включая как сотрудников неэффективных госпредприятий, так и работающих с ними частных фирм, и это, в условиях острой нехватки у государства финансовых ресурсов для их поддержки, скажется на социальной стабильности в стране [16]. Вместе с тем консервация нынешней модели (и в этом сходятся почти

9. Так, в июне 2016 г., характеризуя Программу социально-экономического развития на 2016-2020 г2., президент Республики Беларусь подчеркнул: «Это программа эволюиии, а не револючии. В ней мы твердо сохраняем преемственность нашего курса и базовые основы белорусской модели развития» [6]. 
все эксперты) обрекает белорусскую экономику на стагнацию и упадок, поэтому ее существенная коррекция необходима, неизбежна и, как показано выше, уже начала осуществляться.

Министерством экономики Республики Беларусь при участии зарубежных экспертов еще осенью 2015 г. была подготовлена «дорожная карта» структурных реформ, включающая шесть блоков: 1) макроэкономическая стабильность, обеспечиваемая при помощи жесткой денежно-кредитной политики; 2) формирование эффективных финансовых рынков для распределения капитала, последовательное сокращение нерыночных кредитов; 3) трансформация государственного сектора, включающая, в частности, реструктуризацию госкомпаний, сокращение господдержки и предоставление ее на конкурсных принципах, переход от директивного планирования к индикативному; 4) создание рабочих мест в частном секторе путем формирования благоприятного инвестиционного климата; 5) новый подход к рынку труда, предполагающий защиту не собственно рабочих мест, а возможности людей получать доход, в том числе на новых или других рабочих местах; 6) развитие конкуренции, включающее широкий спектр институциональных и секторальных реформ [9]. Первоначально «дорожная карта» была скептически встречена высшим руководством страны и многими экспертами, но ныне, в условиях нарастающих трудностей в экономике, ее идеи, на наш взгляд, становятся весьма актуальными.

Переход к новой модели хозяйствования в любом случае будет болезненным, затронет ключевые отрасли белорусской экономики и социальную сферу. В этой связи важно правильно определить «пределы» реформирования, не допуская перехода грани, за которой неоправданно быстрое и недостаточно подготовленное развитие рыночных отношений может нанести недопустимый ущерб интересам государства и большинства населения. Чисто либеральная модель с минимизацией государственного регулирования экономики, на наш взгляд, едва ли приемлема для современной Белоруссии. Более перспективна, видимо, «смешанная» модель, где государство оказывает активное воздействие на экономику с помощью косвенных рычагов (налоговой, денежно-кредитной политики и др.) при значительной либерализации хозяйственной деятельности и активизации рыночных отношений. Возможности и риски реализации в Республике Беларусь такой модели требуют специального исследования. 


\section{Библиография}

1. Аникеев М. Белорусская экономическая модель: Истоки кризиса. URL: http://udf.by/ news/sobytie/136183-belorusskaya-ekonomicheskaya (Дата обращения: 05.12.2016.)

2. Баланс внешней торговли товарами Республики Беларусь. URL: http://belstat.gov.by/ ofitsialnaya-statistika/otrasli-statistiki/torgovly (Дата обращения: 15.02.2016.)

3. Белорусская экономическая модель как основа идеологии государства // URL: http://gendocs.ru/v35999/\%D0\%B1\%D0\%B5\%D0\%BB0\%D0\% (Дата обращения: 06.12.2016.)

4. Белорусская экономическая модель: На смертном одре или перед подъемом в гору // URL: http://rodon.org/polit-110729120114 (Дата обращения: 06.12.2016.)

5. Бобровницкая Н. Прогресс без участия государства // Белорусы и рынок. 2016. 1623 апр.

6. Герасименко А. За перемены без перемен // Белорусы и рынок. 2016. 26 июня - 2 июля.

7. Герасименко А. Светлое будущее для бизнеса // Белорусы и рынок. 2017. 14-20 янв.

8. Годин Ю. Белоруссия - это «Брестская крепость» современной России. М.: Издательство ИТРК, 2008. 184 с.

9. Голубь Е. Дорожная карта бита // Белорусы и рынок. 2015. 7-13 нояб.

10. 25 лет Содружеству Независимых Государств. 1991-2015. Статистический сборник. M., 2016. 500 c.

11. 10 лет Содружества Независимых Государств (1991-2000). Статистический сборник. M, 2001. $802 \mathrm{c}$.

12. Дорохов В. Белорусская экономическая модель: Плюсы, минусы и перспективы выживания // URL: http://www.dw.com/ru/\%D0\%B1\%D0\%B5\%D0\%BB\%D0\%BE (Дата обращения: 06.12.2016.) тября.

13. Калиновская Т. Госпредприятия: Трудное решение // Белорусы и рынок. 2016. 1-7 ок-

14. Калиновская Т., Алексеев В. Загадки белорусской модели // Белорусы и рынок. 24 декаб. 2016 - 14 янв. 2017.

15. Кнобель А. Евразийский экономический союз: Перспективы развития и возможные препятствия // Вопросы экономики. 2015. № 3. С. 87-108.

16. Лавникевич Д. Это не касается стыда перед // БелГазета. 2016. 17 окт.

17. Лосев М. Заповедная экономика // РБК. 2011. № 1. С. 36-39.

18. Национальная экономика Беларуси / Под ред. В.Н. Шимова. 4-е изд., перераб. и доп. Минск: БГЭУ, 2012. $651 \mathrm{c.}$

19. Пожидаев Е. Белорусский кризис: Девальвация Лукашенко // URL: https://eadaily.com/ ru/news/2016/12/29/belorusskiy-krizis-devalva (Дата обращения: 11.01.2017.)

20. 15 лет Содружества Независимых Государств (1991-2005). Статистический сборник. M., 2006. $437 \mathrm{c}$.

21. Романчук Я. Сообразим по $\$ 500 / /$ БелГазета. 2016. 21 нояб.

22. Рудый К. Государственный капитализм в Беларуси // Мировая экономика и международные отношения. 2016. № 4. С. 77-85.

23. Содружество Независимых Государств в 2014 году. Статистический ежегодник. М., 2015. $631 \mathrm{c}$.

24. Социально-экономическое положение Республики Беларусь. Янв. - декаб. 2016 г. // URL: http://www.belstat.gov.by (Дата обращения: 30.01.2017.)

25. Стасюлевич Н. Белорусы продолжают занимать // Белорусы и рынок. 2016. 3-9 декаб.

26. Статистический ежегодник Республики Беларусь. 2015 год. Минск, 2015. 524 с. 


\section{References}

Anikeev M. Belorusskaja jekonomicheskaja model': Istoki krizisa. URL: http://udf.by/ news/sobytie/136183-belorusskaya-ekonomicheskaya (Data obrashhenija: 05.12.2016.)

Balans vneshnej torgovli tovarami Respubliki Belarus'. URL: http://belstat.gov.by/ofitsialnayastatistika/otrasli-statistiki/torgovly (Data obrashhenija: 15.02.2016.)

Belorusskaja jekonomicheskaja model' kak osnova ideologii gosudarstva // URL: http://gendocs. ru/v35999/\%D0\%B1\%D0\%B5\%D0\%BB0\%D0\% (Data obrashhenija: 06.12.2016.)

Belorusskaja jekonomicheskaja model': Na smertnom odre ili pered pod\#emom v goru // URL: http://rodon.org/polit-110729120114 (Data obrashhenija: 06.12.2016.)

Bobrovnickaja N. Progress bez uchastija gosudarstva // Belorusy i rynok. 2016. 16-23 Apr.

10 let Sodruzhestva Nezavisimyh Gosudarstv (1991-2000). Statisticheskij sbornik. Moscow, 2001.802 p.

Dorohov V. Belorusskaja jekonomicheskaja model': Pljusy, minusy i perspektivy vyzhivanija // URL: http://www.dw.com/ru/\%D0\%B1\%D0\%B5\%D0\%BB\%D0\%BE (Data obrashhenija: 06.12.2016.)

25 let Sodruzhestvu Nezavisimyh Gosudarstv. 1991-2015. Statisticheskij sbornik. Moscow, 2016. 500 p.

Gerasimenko A. Svetloe budushhee dlja biznesa // Belorusy i rynok. 2017. 14-20 Jan.

Gerasimenko A. Za peremeny bez peremen // Belorusy i rynok. 2016. 26 Jun. - 2 Jul.

Godin Ju. Belorussija - jeto «Brestskaja krepost'» sovremennoj Rossii. M.: Izdatel'stvo ITRK, 2008. 184 p.

Golub' E. Dorozhnaja karta bita // Belorusy i rynok. 2015. 7-13 Nov.

Kalinovskaja T. Gospredprijatija: trudnoe reshenie // Belorusy i rynok. 2016. 1-7 Oct.

Kalinovskaja T., Alekseev V. Zagadki belorusskoj modeli // Belorusy i rynok. 24 Dec 2016 14 Jan 2017.

Knobel' A. Evrazijskij jekonomicheskij sojuz: Perspektivy razvitija i vozmozhnye prepjatstvija // Voprosy jekonomiki. 2015. N 3. P. 87-108.

Lavnikevich D. Jeto ne kasaetsja styda pered // BelGazeta. 2016. 17 Oct.

Losev M. Zapovednaja jekonomika // RBK. 2011. N 1. P. 36-39.

Nacional'naja jekonomika Belarusi / Pod red. V.N. Shimova. 4-e izd., pererab. i dop. Minsk: BGJeU, 2012. 651p.

15 let Sodruzhestva Nezavisimyh Gosudarstv (1991-2005). Statisticheskij sbornik. Moscow, 2006. 437 p.

Pozhidaev E. Belorusskij krizis: deval'vacija Lukashenko // URL: https://eadaily.com/ru/ news/2016/12/29/belorusskiy-krizis-devalva (Data obrashhenija: 11.01.2017.)

Romanchuk Ja. Soobrazim po \$500 // BelGazeta. 2016. 21 Nov.

Rudyj K. Gosudarstvennyj kapitalizm v Belarusi // Mirovaja jekonomika i mezhdunarodnye otnoshenija. 2016. N 4. P. 77-85.

Social'no-jekonomicheskoe polozhenie Respubliki Belarus'. Janv. - dekab. 2016 g. // URL: http://www.belstat.gov.by (Data obrashhenija: 30.01.2017.) $631 \mathrm{p}$.

Sodruzhestvo Nezavisimyh Gosudarstv v 2014 godu. Statisticheskij ezhegodnik. Moscow, 2015.

Stasjulevich N. Belorusy prodolzhajut zanimat' // Belorusy i rynok. 2016. 3-9 Dec.

Statisticheskij ezhegodnik Respubliki Belarus'. 2015 god. Minsk, 2015. 524 p. 